\title{
Ochrobactrum oryzae sp. nov., an endophytic bacterial species isolated from deep-water rice in India
}

Correspondence

Michael Schloter

schloter@gsf.de

\author{
Anil K. Tripathi, ${ }^{1}$ Subhash C. Verma,${ }^{1}$ Soumitra Paul Chowdhury, ${ }^{1}$ \\ Michael Lebuhn, ${ }^{2}$ Andreas Gattinger ${ }^{3}$ and Michael Schloter ${ }^{3}$
${ }^{1}$ School of Biotechnology, Faculty of Science, Banaras Hindu University, Varanasi - 221005, India \\ ${ }^{2}$ Institute of Water Quality Control and Waste Management, Technical University of Munich, Am \\ Coulombwall, 85748 Garching, Germany \\ ${ }^{3}$ GSF-National Centre for Environment and Health, Institute of Soil Ecology, Ingolstaedter \\ Landstrasse 1, 85764 Neuherberg, Germany
}

\begin{abstract}
A non-pigmented, motile, Gram-negative bacterium designated MTCC $4195^{\top}$ was isolated from surface-sterilized seeds and plant tissue from deep-water rice (Oryza sativa) cultivated in Suraha Tal Lake in northern India. This isolate was shown to reinfect and colonize deep-water rice endophytically. The highest level of $16 \mathrm{~S}$ rRNA sequence similarity (96.8\%) to strain MTCC $4195^{\top}$ was shown by Ochrobactrum gallinifaecis DSM $15295^{\top}$. Strain MTCC $4195^{\top}$ utilized $\gamma$-hydroxybutyric acid, adonitol, D-glucosaminic acid and arabinose as carbon sources, but failed to use gentiobiose or citrate. The cell-wall fatty acids of strain MTCC $4195^{\top}$ were characterized by the presence of a relatively large proportion of $\mathrm{C}_{18: 1} \omega 7 \mathrm{C}$ and a relative small proportion of $\mathrm{C}_{16 \text { :0 }}$ in comparison with Ochrobactrum species. DNA-DNA relatedness studies showed less than $52 \%$ binding with the DNAs of type strains of other species of the genus Ochrobactrum. On the basis of phenotypic and genotypic characteristics and the results of $16 \mathrm{~S}$ rRNA gene sequence analysis, the novel species Ochrobactrum oryzae sp. nov. is proposed, with MTCC $4195^{\top}\left(=\mathrm{DSM} 17471^{\top}\right)$ as the type strain.
\end{abstract}

A search for endophytic plant-growth-promoting bacteria in rice demonstrated the ability of some strains of Herbaspirillum, Acetobacter, Azoarcus, Serratia and Pantoea to colonize rice tissues endophytically (Cocking, 2003). Endophytes of rice include diverse types of nitrogen-fixing and non-nitrogen-fixing bacteria, which are found mainly in the roots, culms and seeds of various wild, traditional and cultivated varieties of rice (Barraquio et al., 1997). The diversity of the endophytic bacteria associated with five varieties of deep-water rice has been characterized (Verma et al., 2001). Analysis of the genotypic diversity of the endophytic bacterial communities present inside the seeds and other tissues of five varieties of deep-water rice revealed that seven different ARDRA (amplified ribosomal DNA restriction analysis) types were present in each rice variety. On the basis of the carbon-utilization pattern obtained, one of these seven ARDRA types showed greatest similarity to members of the genus Ochrobactrum (Kämpfer et al., 2003).

Abbreviation: ARDRA, amplified ribosomal DNA restriction analysis. The GenBank/EMBL/DDBJ accession number for the 16S rRNA gene sequence of strain MTCC $4195^{\top}$ is $\mathrm{AMO} 41247$.
Two other recent reports have described the isolation of Ochrobactrum strains from nodules of Acacia mangium (Ngom et al., 2004) and Lupinus albus (Trujillo et al., 2005). Comparison of the 16S rRNA gene sequences of Ochrobactrum isolates from A. mangium showed $98 \%$ sequence similarity with Ochrobactrum intermedium and Ochrobactrum anthropi (Ngom et al., 2004), whereas the 16S rRNA gene sequence of the proposed type strain of 'Ochrobactrum lupini showed $100 \%$ similarity with that of O. anthropi, and further investigations are necessary to confirm the status of 'O. lupini' as a distinct species (Trujillo et al., 2005). Interestingly, analysis of the plasmid profile of 'O. lupini' showed the presence of three plasmids carrying nodD and nifH genes.

The aim of the present study was to characterize the taxonomic position of strain MTCC $4195^{\mathrm{T}}$, isolated as an endophyte from samples taken from five varieties of deepwater rice, with respect to the type strains of species of Ochrobactrum with validly published names.

Seeds from deep-water rice (Oryza sativa varieties Jaisurya, Kariyawa, Supankhi, Tudihiwa and Sigra) were surfacesterilized by treatment with $1 \%$ chloramine $\mathrm{T}$ for $15 \mathrm{~min}$ 
(Barraquio et al., 1997), thoroughly macerated, resuspended in $5 \mathrm{ml} \mathrm{PBS} \mathrm{(pH} \mathrm{7 \cdot 0)}$ and shaken for $15 \mathrm{~min}$ at 200 r.p.m. in an orbital shaker at room temperature. This suspension was used, after serial dilution, to inoculate nitrogen-free semi-solid medium containing malate as the carbon source (Albrecht \& Okon, 1980) and incubated at $30^{\circ} \mathrm{C}$. A subsurface pellicle appeared after $24 \mathrm{~h}$. This was vortexed and transferred to fresh nitrogen-free semi-solid medium to enrich for microaerophilic, diazotrophic bacteria. After the fifth subculture, appropriate dilutions of the vortexed suspensions were spread on nutrient agar plates. Twenty randomly selected colonies isolated from the seeds of each of the five varieties were subjected to phylogenetic study. From a taxonomic point of view, 16 of the isolates were of great interest because of their ARDRA pattern (Heyndrickx et al., 1996), which was very similar to those of members of the genus Ochrobactrum. REP-PCR (Versalovic et al., 1994) and ERIC-PCR (Gillings \& Holley, 1997) fingerprinting indicated that all 16 isolates were identical. The inability of the REP-PCR to reveal any genotypic differences among the 16 isolates could be because the endophytic environment resulted in genetic isolation and strong selection pressure preventing genotypic diversity within the species. A very low level of genotypic diversity was observed previously in Ochrobactrum tritici strains isolated from the rhizosphere of wheat (Lebuhn et al., 2000). As genotypic diversity was not observed (Christensen et al., 2001), we used only one isolate, MTCC $4195^{\mathrm{T}}$, for further identification. The characteristic ARDRA and genomic fingerprints of MTCC $4195^{\mathrm{T}}$ were present only in the seeds and tissues of five varieties of deep-water rice and were absent from the water, sediments and soils of the rice-cultivation site.

The cells were stained according to the Gram procedure described by Doetsch (1981). Motility was investigated using phase-contrast microscopy after growth in nutrient broth at $30^{\circ} \mathrm{C}$ for $48 \mathrm{~h}$. The position of the flagellum and the cell size were determined using scanning electron microscopy. Cell growth on nutrient agar plates was tested at different temperatures for $48 \mathrm{~h}$. Additionally, the $\mathrm{pH}$ range and $\mathrm{pH}$ optimum for growth of strain MTCC $4195^{\mathrm{T}}$ were determined in liquid culture for $48 \mathrm{~h}$ at $30^{\circ} \mathrm{C}$, using buffers containing phosphate salts. The results are presented in the species description.

To determine the cellular fatty acid pattern, the procedure described by Gattinger et al. (2002) was used. Cells of reference type strains and strain MTCC $4195^{\mathrm{T}}$ were grown in nutrient broth medium for $24 \mathrm{~h}$ at $30^{\circ} \mathrm{C}$. Clear differences were observed in the fatty acid methyl ester patterns of different Ochrobactrum species. Although fatty acid $\mathrm{C}_{18: 1} \omega 7 c$ was predominant in all extracts from the type strains of the five Ochrobactrum species and MTCC $4195^{\mathrm{T}}$, there were clear quantitative differences. Whereas the content of $\mathrm{C}_{18: 1} \omega 7 c$ in extracts of O. anthropi DSM $6882^{\mathrm{T}}$ and O. intermedium LMG $3301^{\mathrm{T}}$ constituted, respectively, only $45 \cdot 1$ and $41 \cdot 4 \%$ of total fatty acid methyl ester content, the figure for strain MTCC $4195^{\mathrm{T}}$ was $65 \cdot 2 \%$. The largest content $(70 \cdot 9 \%)$ was found in Ochrobactrum grignonense DSM $13338^{\mathrm{T}}$. However, the most significant differences were found with respect to the saturated fatty acid fraction. The $\mathrm{C}_{16: 0}$ content in strain MTCC $4195^{\mathrm{T}}(5 \cdot 1 \%)$ was significantly smaller than those of the type strains of O. anthropi, O. tritici, Ochrobactrum gallinifaecis and O. intermedium. A large content of the fatty acid $\mathrm{C}_{19: 0}$ cyclo $(16 \cdot 5 \%)$ was characteristic of strain MTCC $4195^{\mathrm{T}}$ and contrasted with the content in the type strain of $O$. grignonense $(9 \cdot 4 \%)$. The cellular fatty acid profiles of the strains investigated are given in Table 1.

The capacity to oxidize different carbon sources was analysed using the Microlog GN2 system (Biolog). The procedure, including growth, inoculation of plates and incubation, was performed according to the manufacturer's

Table 1. Fatty acid methyl ester compositions of members of the genus Ochrobactrum

Strains: 1, O. anthropi DSM $6882^{\mathrm{T}} ; 2$, O. intermedium LMG $3301^{\mathrm{T}}$; 3, O. tritici DSM $13340^{\mathrm{T}}$; 4, O. grignonense DSM $13338^{\mathrm{T}}$; 5, O. oryzae sp. nov. MTCC $4195^{\mathrm{T}}$. Values are percentages of total fatty acid methyl esters.

\begin{tabular}{|c|c|c|c|c|c|}
\hline $\begin{array}{l}\text { Fatty acid } \\
\text { methyl ester }\end{array}$ & 1 & 2 & 3 & 4 & 5 \\
\hline $\mathrm{C}_{16: 1} \omega 6$ & $0 \cdot 2$ & $<0 \cdot 1$ & $0 \cdot 3$ & $<0 \cdot 1$ & $<0 \cdot 1$ \\
\hline $\mathrm{C}_{16: 1} \omega 7 c$ & $1 \cdot 7$ & $1 \cdot 1$ & $1 \cdot 6$ & $1 \cdot 6$ & $0 \cdot 94$ \\
\hline $\mathrm{C}_{18: 1} \omega 9$ & $<0 \cdot 1$ & $0 \cdot 1$ & $0 \cdot 5$ & $0 \cdot 1$ & $<0 \cdot 1$ \\
\hline $\mathrm{C}_{18: 1} \omega 7 c$ & $45 \cdot 1$ & $41 \cdot 4$ & $52 \cdot 6$ & $70 \cdot 9$ & $65 \cdot 2$ \\
\hline $\mathrm{C}_{18: 1} \omega 7 t$ & $0 \cdot 1$ & $0 \cdot 1$ & $0 \cdot 1$ & $<0 \cdot 1$ & $0 \cdot 1$ \\
\hline $\mathrm{C}_{10: 1} 9-\mathrm{OH}$ & $0 \cdot 1$ & $0 \cdot 2$ & $0 \cdot 2$ & $<0 \cdot 1$ & $0 \cdot 1$ \\
\hline $\mathrm{C}_{9: 0}$ dihydroxy & $<0 \cdot 1$ & $<0 \cdot 1$ & $0 \cdot 1$ & $<0 \cdot 1$ & $<0 \cdot 1$ \\
\hline $\mathrm{C}_{11: 1} 11-\mathrm{OH}$ & $0 \cdot 1$ & $<0 \cdot 1$ & $0 \cdot 1$ & $<0 \cdot 1$ & $0 \cdot 1$ \\
\hline $\mathrm{C}_{12: 0} 11-\mathrm{OH}$ & $0 \cdot 1$ & $<0 \cdot 1$ & $0 \cdot 1$ & $<0 \cdot 1$ & $<0 \cdot 1$ \\
\hline $\mathrm{C}_{12: 1} 11-\mathrm{OH}$ & $0 \cdot 1$ & $0 \cdot 2$ & $0 \cdot 3$ & $<0 \cdot 1$ & $0 \cdot 1$ \\
\hline $\mathrm{C}_{13: 1} 13-\mathrm{OH}$ & $0 \cdot 2$ & $0 \cdot 1$ & $0 \cdot 2$ & $<0 \cdot 1$ & $0 \cdot 1$ \\
\hline $\mathrm{C}_{16: 0}$ methoxy & $1 \cdot 4$ & $1 \cdot 5$ & $1 \cdot 5$ & $0 \cdot 4$ & $1 \cdot 0$ \\
\hline $\mathrm{C}_{15: 1} 15-\mathrm{OH}$ & $0 \cdot 3$ & $0 \cdot 2$ & $0 \cdot 2$ & $<0 \cdot 1$ & $0 \cdot 2$ \\
\hline $\mathrm{C}_{16: 1} 15-\mathrm{OH}$ & $0 \cdot 9$ & $0 \cdot 8$ & $0 \cdot 1$ & $<0 \cdot 1$ & $0 \cdot 7$ \\
\hline $\mathrm{C}_{18: 0}$ cyclo $2-\mathrm{OH}$ & $0 \cdot 3$ & $1 \cdot 7$ & $1 \cdot 0$ & $1 \cdot 3$ & $1 \cdot 8$ \\
\hline $\mathrm{C}_{17: 2} 16-\mathrm{OH}$ & $0 \cdot 1$ & $0 \cdot 1$ & $<0 \cdot 1$ & $<0 \cdot 1$ & $<0 \cdot 1$ \\
\hline $\mathrm{C}_{19: 0}$ cyclo $2-\mathrm{OH}$ & $0 \cdot 1$ & $0 \cdot 3$ & $0 \cdot 2$ & $0 \cdot 1$ & $0 \cdot 1$ \\
\hline $\mathrm{C}_{14: 0}$ & $0 \cdot 3$ & $0 \cdot 2$ & $1 \cdot 0$ & $<0 \cdot 1$ & $0 \cdot 1$ \\
\hline $\mathrm{C}_{15: 0}$ iso & $<0 \cdot 1$ & $<0 \cdot 1$ & $0 \cdot 1$ & $<0 \cdot 1$ & $<0 \cdot 1$ \\
\hline $\mathrm{C}_{15: 0}$ anteiso & $0 \cdot 1$ & $<0 \cdot 1$ & $0 \cdot 1$ & $<0 \cdot 1$ & $<0 \cdot 1$ \\
\hline $\mathrm{C}_{15: 0}$ & $0 \cdot 1$ & $0 \cdot 1$ & $0 \cdot 1$ & $<0 \cdot 1$ & $<0 \cdot 1$ \\
\hline $\mathrm{C}_{16: 0}$ iso & $0 \cdot 1$ & $0 \cdot 1$ & $0 \cdot 1$ & $<0 \cdot 1$ & $<0 \cdot 1$ \\
\hline $\mathrm{C}_{16: 0}$ & $10 \cdot 0$ & $10 \cdot 4$ & $15 \cdot 1$ & $7 \cdot 7$ & $5 \cdot 1$ \\
\hline $\mathrm{C}_{17: 0}$ anteiso & $<0 \cdot 1$ & $0 \cdot 1$ & $0 \cdot 1$ & $<0 \cdot 1$ & $<0 \cdot 1$ \\
\hline $\mathrm{C}_{17: 0}$ cyclo & $0 \cdot 4$ & $0 \cdot 4$ & $0 \cdot 1$ & $<0 \cdot 1$ & $<0 \cdot 1$ \\
\hline $\mathrm{C}_{17: 0}$ & $0 \cdot 6$ & $0 \cdot 3$ & $0 \cdot 4$ & $0 \cdot 3$ & $0 \cdot 3$ \\
\hline $\mathrm{C}_{18: 0}$ & $8 \cdot 4$ & $7 \cdot 8$ & $8 \cdot 1$ & $7 \cdot 7$ & $5 \cdot 6$ \\
\hline $\mathrm{C}_{19: 0}$ cyclo & $26 \cdot 4$ & $30 \cdot 7$ & $14 \cdot 1$ & $9 \cdot 4$ & $16 \cdot 5$ \\
\hline $\mathrm{C}_{20: 0}$ & $0 \cdot 1$ & $0 \cdot 1$ & $0 \cdot 1$ & $<0 \cdot 1$ & $0 \cdot 1$ \\
\hline
\end{tabular}


instructions. Strain MTCC $4195^{\mathrm{T}}$ showed most similarity to O. anthropi DSM $6882^{\mathrm{T}}$ (differences were apparent only in the utilization of gentiobiose and arabinose) and $O$. tritici DSM $13340^{\mathrm{T}}$ (differences were found in the utilization of $\gamma$-hydroxybutyric acid and arabinose). Strain MTCC $4195^{\mathrm{T}}$ could be distinguished from O. intermedium LMG $3301^{\mathrm{T}}$ on the basis of utilization of gentiobiose, citrate and arabinose; O. grignonense DSM $13338^{\mathrm{T}}$ differed from strain MTCC $4195^{\mathrm{T}}$ in the utilization of adonitol, D-glucosaminic acid and citrate. O. gallinifaecis DSM $15295^{\mathrm{T}}$ was the most distant relation of MTCC $4195^{\mathrm{T}}$ and differed from the novel strain in terms of the utilization of $\gamma$-hydroxybutyric acid, adonitol, D-glucosaminic acid and gentiobiose. The results are summarized in Table 2.

The complete 16S rRNA gene sequence of strain MTCC $4195^{\mathrm{T}}$ showed the highest level of similarity $(96 \cdot 8 \%)$ with $O$. gallinifaecis DSM $15295^{\mathrm{T}}$. Comparison and alignment of the complete 16S rRNA gene sequence of strain MTCC $4195^{\mathrm{T}}$ was done according to Lebuhn et al. (2000). A phylogenetic tree was constructed by using neighbour-joining analysis (Fig. 1). The tree was rooted using Mycoplana dimorpha IAM $13154^{\mathrm{T}}$ as the outgroup. Identical tree topologies were obtained using other algorithms, such as maximum parsimony and maximum likelihood (puzzle) (not shown). The results clearly indicate that strain MTCC $4195^{\mathrm{T}}$ is distantly related to $O$. anthropi, $O$. tritici, $O$. intermedium and $O$. grignonense. On the basis of the 16S rRNA gene sequence, the closest relative of strain MTCC $4195^{\mathrm{T}}$ is O. gallinifaecis.

As the 16S rRNA gene sequence similarity between the novel isolate and Ochrobactrum species was less than $97 \%$, strain MTCC $4195^{\mathrm{T}}$ may represent a novel species of the genus Ochrobactrum. DNA-DNA hybridization studies of the strain with standard reference strains of the five Ochrobactrum species were performed according to Ziemke et al. (1998). The results showed that strain MTCC $4195^{\mathrm{T}}$ did not have sufficient DNA relatedness to be assigned to any known species of the genus Ochrobactrum. The highest level of DNA relatedness $(52 \cdot 7 \%)$ was found with respect to $O$.

Table 2. Capacity to oxidize carbon sources by members of the genus Ochrobactrum, as determined using the Biolog system

Strains: 1, O. anthropi DSM $6882^{\mathrm{T}} ; 2$, O. intermedium LMG $3301^{\mathrm{T}}$; 3, O. tritici DSM $13340^{\mathrm{T}}$; 4, O. grignonense DSM $13338^{\mathrm{T}}$; 5, O. gallinifaecis DSM $15295^{\mathrm{T}} ; 6$, O. oryzae MTCC $4195^{\mathrm{T}}$. +, Positive; - , negative; $(+)$, weakly positive.

\begin{tabular}{|lcccccc|}
\hline Carbon source & $\mathbf{1}$ & $\mathbf{2}$ & $\mathbf{3}$ & $\mathbf{4}$ & $\mathbf{5}$ & $\mathbf{6}$ \\
\hline$\gamma$-Hydroxybutyric acid & + & + & - & + & - & + \\
Adonitol & + & + & + & - & - & + \\
D-Glucosaminic acid & + & + & + & - & - & + \\
Gentiobiose & + & + & - & - & $(+)$ & - \\
Citrate & - & + & - & + & - & - \\
Arabinose & - & - & - & + & + & + \\
\hline
\end{tabular}

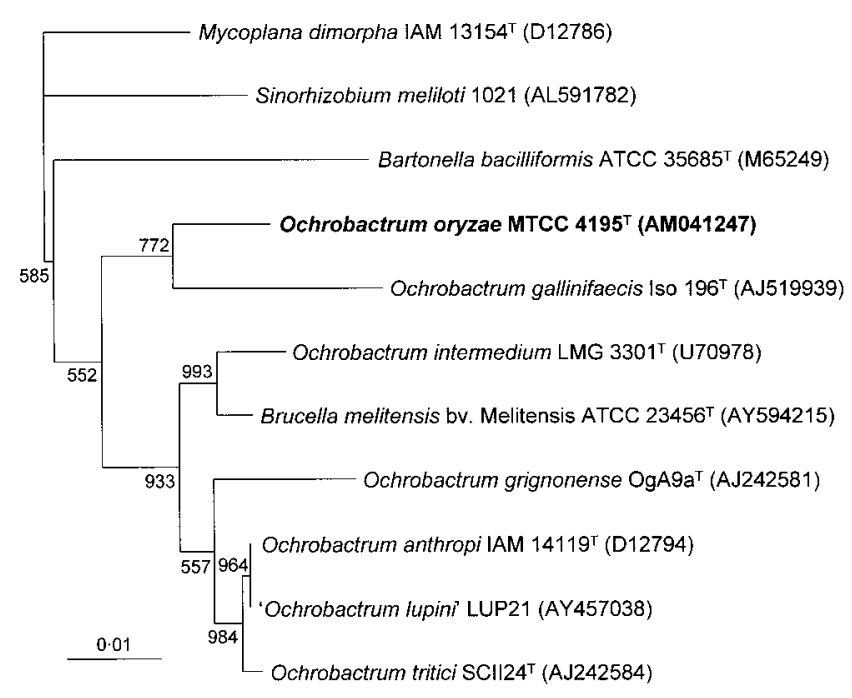

Fig. 1. CLUSTREE neighbour-joining tree based on 16S rRNA gene sequences (1374 nt) of Ochrobactrum oryzae sp. nov. MTCC $4195^{\top}$ and related species of the genus Ochrobactrum. The Kimura two-parameter model was used as a substitution model, and multiple substitutions were not considered. Bootstrap probabilities were obtained from 1000 subsets. Gaps were treated as a fifth nucleotide state. Bar, 0.01 substitutions per site.

gallinifaecis DSM $15295^{\mathrm{T}}$. The levels of DNA relatedness with $O$. anthropi DSM $6882^{\mathrm{T}}(43.5 \%)$, O. intermedium LMG $3301^{\mathrm{T}}(22 \cdot 7 \%)$, O. tritici DSM $13340^{\mathrm{T}}(23 \cdot 5 \%)$ and O. grignonense DSM $13338^{\mathrm{T}}(21 \cdot 8 \%)$ were significantly lower. Standard deviations for all hybridization experiments did not exceed $15 \%$.

As Ochrobactrum belongs to the Rhizobiales, and as rhizobia are known to possess the ability to fix nitrogen, it was considered worthwhile to investigate whether nifH sequences were present in the genome of strain MTCC $4195^{\mathrm{T}}$, particularly as there are entries in the NCBI database that suggest that some Ochrobactrum strains might be able to fix nitrogen. Amplification of nifH sequences was performed by using the primers described by Ueda et al. (1995). An amplicon of $390 \mathrm{bp}$ was generated from all of the known nitrogen-fixing bacteria but not from strain MTCC $4195^{\mathrm{T}}$. The ability of strain MTCC $4195^{\mathrm{T}}$ to colonize deep-water rice endophytically was demonstrated by genetically tagging the strain with a constitutively expressed GFP (green fluorescent protein) reporter, reinfecting gnotobiotically grown rice seedlings with $g f p$-tagged MTCC $4195^{\mathrm{T}}$ and localizing expression within the plant tissues by means of confocal laser scanning microscopy (Verma et al., 2004).

\section{Description of Ochrobactrum oryzae sp. nov.}

Ochrobactrum oryzae (L. fem. gen. n. oryzae of rice, pertaining to the habitat from which the first strains were isolated). 
Cells are Gram-negative, aerobic (oxidase- and catalasepositive), non-spore-forming rods $(0 \cdot 8 \times 1 \cdot 4 \mu \mathrm{m})$, producing non-pigmented, translucent to milky white, circular, convex, smooth colonies on nutrient agar; typical growth occurs between 10 and $37^{\circ} \mathrm{C}$ (optimum, $30^{\circ} \mathrm{C}$ ) and between pH 4 and 9 (optimum, pH 6-7). Cells are motile by means of a polar flagellum. Utilization of various carbon sources was determined using the Biolog test system. Positive test results were obtained for the following: $\alpha$-cyclodextrin, glycogen, Tweens 40 and 80, $N$-acetyl-D-galactosamine, $\mathrm{N}$-acetyl-D-glucosamine, adonitol, L-arabinose, D-arabitol, i-erythritol, D-fructose, L-fucose, D-galactose, $\alpha$-D-glucose, myo-inositol, maltose, D-mannitol, D-mannose, psicose, L-rhamnose, D-sorbitol, sucrose, turanose, methyl pyruvate, succinic acid monomethyl ester, acetic acid, cis-aconitic acid, D-galactonic acid lactone, D-gluconic acid, D-glucosaminic acid, $\alpha$-hydroxybutyric acid, $\beta$-hydroxybutyric acid, $\gamma$-hydroxybutyric acid, $\alpha$-ketoglutaric acid, DL-lactic acid, propionic acid, succinic acid, bromosuccinic acid, alaninamide, D-alanine, L-alanine, L-alanyl glycine, L-asparagine, L-aspartic acid, L-glutamic acid, glycyl L-aspartic acid, glycyl L-glutamic acid, L-histidine, hydroxy-L-proline, L-leucine, L-ornithine, D-serine, L-threonine, $\gamma$-aminobutyric acid, inosine and uridine. Negative Biolog reactions were obtained for dextrin, gentiobiose, D-melibiose, methyl $\beta$-D-glucosamide, D-raffinose, xylitol, citric acid, D-galacturonic acid, p-hydroxyphenylacetic acid, itaconic acid, D-saccharic acid, L-phenylalanine, L-pyroglutamic acid, thymidine, phenylethylamine, putrescine, 2-aminoethanol, 2,3-butanediol and glucose 1-phosphate. Predominant fatty acids are $\mathrm{C}_{18: 1} \omega 7 \mathrm{c}$ $(65 \cdot 2 \%)$ and $\mathrm{C}_{19: 0}$ cyclo $(16 \cdot 5 \%)$. In addition, significant amounts of $\mathrm{C}_{16: 0}(5 \cdot 1 \%)$ and $\mathrm{C}_{18: 0}$ cyclo $2-\mathrm{OH}(1 \cdot 8 \%)$ are detected.

The type strain, MTCC $4195^{\mathrm{T}}\left(=\mathrm{DSM} 17471^{\mathrm{T}}\right)$, was isolated from surface-sterilized seeds and plant tissue from deep-water rice (Oryza sativa) cultivated in Suraha Tal Lake in northern India.

\section{References}

Albrecht, S. L. \& Okon, Y. (1980). Culture of Azospirillum. Methods Enzymol 69, 740-749.

Barraquio, W. L., Revilla, L. \& Ladha, J. K. (1997). Isolation of endophytic diazotrophic bacteria from wetland rice. Plant Soil 194, 15-24.

Christensen, H., Bisgaard, M., Frederiksen, W., Mutters, R., Kuhnert, P. \& Olsen, J. E. (2001). Is characterization of a single isolate sufficient for valid publication of a new genus or species? Proposal to modify recommendation $30 \mathrm{~b}$ of the Bacteriological Code (1990 Revision). Int J Syst Evol Microbiol 51, 2221-2225.
Cocking, E. C. (2003). Endophytic colonization of plant roots by nitrogen-fixing bacteria. Plant Soil 252, 169-175.

Doetsch, R. N. (1981). Determinative methods of light microscopy. In Manual of Methods for General Bacteriology, pp. 21-33. Edited by P. Gerhardt, R. G. E. Murray, R. N. Costilow, E. W. Nester, W. A. Wood, N. R. Krieg \& G. B. Phillips. Washington, DC: American Society for Microbiology.

Gattinger, A., Schloter, M. \& Munch, J. C. (2002). Phospholipid etherlipid and phospholipid fatty acid fingerprints in selected euryarchaeotal monocultures for taxonomic profiling. FEMS Microbiol Lett 213, 133-139.

Gillings, M. \& Holley, M. (1997). Repetitive element PCR fingerprinting (rep-PCR) using enterobacterial repetitive intergenic consensus (ERIC) primers is not necessarily directed at ERIC elements. Lett Appl Microbiol 25, 17-21.

Heyndrickx, M., Vauterin, L., Vandamme, P., Kersters, K. \& De Vos, P. (1996). Applicability of combined amplified ribosomal DNA restriction analysis (ARDRA) patterns in bacterial phylogeny and taxonomy. J Microbiol Methods 26, 247-259.

Kämpfer, P., Buczolits, S., Albrecht, A., Busse, H. J. \& Stackebrandt, E. (2003). Towards a standardized format for the description of a novel species (of an established genus): Ochrobactrum gallinifaecis sp. nov. Int J Syst Evol Microbiol 53, 893-896.

Lebuhn, M., Achouak, W., Schloter, M., Berge, O., Meier, H., Barakat, M., Hartmann, A. \& Heulin, T. (2000). Taxonomic characterization of Ochrobactrum sp. isolates from soil samples and wheat roots, and description of Ochrobactrum tritici sp. nov. and Ochrobactrum grignonense sp. nov. Int J Syst Evol Microbiol 50, 2207-2223.

Ngom, A., Nakagawa, Y., Sawada, H. \& 8 other authors (2004). A novel symbiotic nitrogen-fixing member of the Ochrobactrum clade isolated from root nodules of Acacia mangium. J Gen Appl Microbiol 50, 17-27.

Trujillo, M. E., Willems, A., Abril, A., Planchuelo, A. M., Rivas, R., Ludena, D., Mateos, P. F., Martinez-Molina, E. \& Velazquez, E. (2005). Nodulation of Lupinus albus by strains of Ochrobactrum lupini sp. nov. Appl Environ Microbiol 71, 1318-1327.

Ueda, T., Suga, Y., Yahiro, N. \& Matsuguchi, T. (1995). Remarkable $\mathrm{N}_{2}$-fixing bacterial diversity detected in rice roots by molecular evolutionary analysis of nifH gene sequences. J Bacteriol 177, 1414-1417.

Verma, S. C., Ladha, J. K. \& Tripathi, A. K. (2001). Evaluation of plant growth promoting and colonization ability of endophytic diazotrophs from deep water rice. J Biotechnol 90, 127-141.

Verma, S. C., Singh, A., Chowdhury, S. P. \& Tripathi, A. K. (2004). Endophytic colonization ability of two deep-water rice endophytes, Pantoea sp. and Ochrobactrum sp. using green fluorescent protein reporter. Biotechnol Lett 26, 425-429.

Versalovic, J., Schneider, M., de Bruijn, F. J. \& Lupski, J. R. (1994). Genomic fingerprinting of bacteria using repetitive sequence based PCR (rep-PCR). Methods Mol Cell Biol 5, 25-40.

Ziemke, F., Höfle, M. G., Lalucat, J. \& Rosselló-Mora, R. (1998). Reclassification of Shewanella putrefaciens Owen's genomic group II as Shewanella baltica sp. nov. Int J Syst Bacteriol 48, 179-186. 